\title{
REGULATING SOCIAL DEVELOPMENT AND THE CONCEPT OF CONTROLLING
}

\author{
Venelin Terziev ${ }^{1}$, Marin Georgiev² ${ }^{2}$ Denis Solovev ${ }^{3}$ \\ ${ }^{1}$ Full Member of the Russian Academy of Natural History, Professor, Eng. \\ D.Sc. (National Security), D.Sc. (Economics), D.Sc. (Social Activities), Ph.D. \\ Russian Academy of Natural History, Moscow, Russia, \\ Vasil Levski National Military University, Veliko Tarnovo, Bulgaria \\ University of Rousse, Rousse, Bulgaria \\ terziev@skmat.com \\ ${ }^{2}$ Ph.D., National Military University, Veliko Tarnovo, Bulgaria, clementon@abv.bg \\ ${ }^{3}$ Associate Professor, Ph.D., Far Eastern Federal University (FEFU), Vladivostok, Russian \\ Federation, solovev.db@dvfu.ru
}

\begin{abstract}
Elucidation of the essesnce of the phenomenon of social programming and its interrelations with management approaches and the concept of controlling is accomplished on the basis of a profound analysis of theory and practice both in historical and conceptual plan deducing the main dependencies between social programming as a basis of the social development and the concept of controlling.
\end{abstract}

Keywords: management, planning, programming, regulation, controlling.

\section{INTRODUCTION}

Modern treating of the term „programming“ defines it as a general principle of management, on which grounds the subject undertakes his actions with certain means in the direction of the goals, in compliance with the dynamic changes of the his surrounding environment. Said in other words, upon the concrete content, structure and dynamic of goal, the activities for its achieving are influenced by the challenges of environment, where the system functions, by the extent of the knowledge about them and the dependence of the subject, its value orientation, the priorities, possibilities it has, the chosen forms and methods for achieving the desired result. This, more than ever defines the necessity of alternativeness of decisions and the choice of optimal variant that contributes to management by results. On that grounds, the so called programme-target approach of management originates, which manifestation is in "Planning-ProgrammingBudgeting-System" (PPBS) (Terziev, 2013), which advantages and disadvantages are among the issues discussed in the presentation alongside the core of social programming as mechanism for management oriented towards results, and the controlling as technology of management in regard to planning and controlling processes standardization (Terziev, 2014).

\section{ADVANTAGES AND DISADVANTAGES OF THE PROGRAMME-TARGET APPROACH OF MANAGEMENT}

Originated in the middle of the 60s in the USA as system for planning, programming and budgeting, the programme-target approach of management is applied in the American army first. Grounded on the idea for 
accelerating the processes of revealing the potential in a system at preliminary set goals, the programmetarget approach penetrates quickly also in civil life in the end of 60 s and the beginning of 70 s (at first in the non-material, and later in the material field, too) (Due J., Friedlander, 1977). This is the reason for PPBS being reviewed as progress in budgeting and as managerial "miracle". In confirmation of that the words of the then USA president Johnson came, according to whom: "This system has to ensure the execution of the new tasks quicker, better and cheaper, through more and of higher quality information, which to generate possibility for better decisions... Our process of making decisions has to have the same level as the one connected with armament and defence. Concisely and clearly said, we have to exchange our donkey's carts for trucks and our old guns for new rockets" (Dickermann und andere, 1971).

What makes the approach unique for application is namely the integration of its three main components goals, programmes, programme-target structure. And if the goals are associated with the mission (the strategy), and from here - the necessity of "unity of goals within the frame of a single organization and the ensuring on the grounds for distributing the organizational resources" (1979), hence also revealing the organizational potential, then the programmes appear to be the specification of the ways the resources for achieving the goals are to be used. For that purpose, each programme contains certain tasks distributed in time and related to the relevant executors. From here, each of the PPBS components expresses particular managerial phases. This way planning determines the long-term goals pointing what is firmly intended to be done. Programming is associated with the analysis and evaluation of the ways and possibilities for achieving the goals (elaboration and selection of alternative programmes) in compliance with the analysis "expenseseffects (benefits)" and the application of quantity methods of management. Said in other words, the programme is a plan with certain time terms (dates), and this way the time when the thing that firmly is intended to be done, is pointed. Budgeting (financing) is associated with the choice of the advantageous and most effective programmes and with their inclusion in the budget for financing and execution. And, as far as budget is nothing else, but a programme with mapped out prices, it gives a notion of how much funds are necessary and when these are to be ensured in order possibility to be ensured for what is firmly intended to be done, to be done at the exact time.

Through the system approach, the pointed managerial phases are integrated in a unified system of interrelated grounds and in a certain relation and subordination to financing. This is the reason one of the most competent experts in the field of programme managing - Charles Hitch (former president of the California University and former assistant secretary of the Ministry of Defence of the USA) to define PPBS as "programme financing", grounded on the principles characterising modern managerial practice. The following principles are of primary significance:

- Long-term nature of goals and the expected end results;

- Prioritization and succession of activities and grading of resources in circumstances of their scarcity;

- Complexity of studying each problem - review of each issue or separate field of activity as system. Here the treating of each system as component of such of a higher rank comes from and the subordination of goals and tasks of the separate sub-systems to the general system's goal;

- Multi-variance of decisions, of the ways and methods for achieving a given goal, which requires elaboration of alternative decisions for action;

- Evaluation and juxtaposing the effectiveness of the separate alternatives on the grounds of objective criteria with the help also of system analysis and its toolkit (modelling, economic-mathematic methods of study and analysis of value, value-effectiveness or value-usefulness, the method of operational studies, machine and game imitating, etc.);

- Continuity of planning or of the application of the so called continuous planning horizon and making the necessary corrections of plans and programmes in the process of their execution;

- Combing the program-target approach in managing with programmes financing in compliance with the extent of achieving the goals.

From here, the application of economic approach to each activity - object of managing, managing grounded on the system approach and analysis, financing on programme-target grounds, which, in their core, are three fundamental theoretic-methodological applications, is grounds for PPBS functioning. This is what defines PPBS as managerial concept of specific goals and tasks. The more-substantial of them are:

- Specifying the national goals;

- Coordinating the activities at the various levels with these goals; 
- Analysis and value evaluation of the possible alternatives for acting;

- Enhancing control's role and effectiveness through financing.

Namely managerial apparatus activity's coordination and its directing for the preliminary set goals' realization appear to be the content of programming. The value evaluation of the possible alternatives and their analysis as well as enhancing control's role, meaning and effectiveness is connected with ensuring the funds, the financing, which is the most substantial system's element. On that ground, the positive features of PPBS are derived, which expression is in:

- The possibility for coordination of planning and preparation for budgeting;

- The application of continuous planning horizon method, on which ground subordination and centralization of the decisions preparation process becomes possible;

- The conduction of analysis of long standing, which allows evaluating the advantages and disadvantages of each possible decision (globally and rationally), and from here, the choice of adequate to the goals alternative;

- Economic grounding of the made decisions regarding expenses usefulness and expedience;

- Taken decisions execution's commitment to their financing, which is expression of both their economizing and effective use of resources.

PPBS leave the impression that it presents the budget as declaration of general policy, which defines the resources necessary for the management end goals achieving. At the same time, the system observes activities as an intermediate stage of transforming the resources into services and usefulness of each programme. And this, in its core, is expression of the subordination "expenses - effects", which is in the base of managing by results.

Of course, PPBS is not deprived of weaknesses. Taking into consideration that some of the goals and tasks have specific nature, experts' opinion is that, "the greatest difficulty and the main weakness of the whole system lays in the fact that it is difficult to formulate sub-goals possible to serve as result operative instruments of the current policy out of the general and universally recognized culturally specific values as peace, freedom, security, justice, education and healthcare" (Dickermann und andere, 1971). Beside the above, from political-juridical point of view, the system widens the possibilities and prerogatives of executive power, while the legislative ones decrease. And this is grounds for conflict between them. To all that, it should be taken into consideration the circumstance that PPBS is not bound with the year cycle at drawing the budget. As a result of that, the practice of duplicating the decisions taken on the grounds of the programmes, synthesis of the various analytical studies and of outlining the future goals is not unusual. Not always are they conformed to the environment's priorities and changes. And not the least, the great documents flow and turnover creates administrative inconveniences and deepens the bureaucratic processes. These are the reasons for PPBS in the end of the 60s and the beginning of $70 \mathrm{~s}$, already transferred from the American army to the civil structures, to stop in its development at doctrinal and experimental level. In the present circumstances, even though it has lost some popularity, PPBS modified variants leave lasting traces in the practice of budgeting. It has been adopted for application also by the newly accepted NATO member states.

\section{PROGRAMMING AS MECHANISM OF MANAGING, ORIENTED TOWARDS RESULTS}

The simultaneous adequate differentiation of the management phases - planning, programming and budgeting, and the proper evaluation of their interaction are in support of choosing these states. We speak here about one intransient merit, which is not to be underestimated. Besides that, it requires special attention at the correlation between revenues and expenses. Particularly, the actual price of the transformed resources necessary for achieving the preliminary set results, defined as possibility or fulfilment of obligation, which is in support of the management by results, of the role and place of programming in the social processes management, is taken into account. And it, the management, applies a certain toolkit for influence upon people, which includes:

- Hierarchy - organization, where the way of influence (attitude towards power) is subordination, the pressure upon a person from above with the help of compulsion, the control over the resource distribution and others similar to these;

- Culture - as manifestation of elaborated and recognized by the society and the organizations groups of 
values, social norms, formulations and stereotypes for behaviour, rituals, requiring people to behave after strictly defined manner;

- The market - expressed through the net of equal in rights relations along the horizontal, grounded on the purchase and sale of various goods, of property, on equilibrium on the interests of seller and purchaser. In live, real economic and social systems they almost always exist. The more important is what is given priority to and what is staked on mostly.

And as far as programming is accompanied by the use of the pointed toolkit of management, the circumstance that it is what is ensured by the organization, which, itself, is hierarchical, with the inherent relations of power, subordination, etc., where there is "systematic, conscious uniting of the activities of people, haunting the achievement of certain goals" (Terziev, 2013), is in support of the statement that it is a general principle of management. And more, of management, oriented towards results.

Something more, this organization ensuring through programming could be presented as number of certain components. The word goes about:

- Connecting the goal with the possible tools for achieving, choice of variant and its establishing in its capacity of a necessary one;

- Elaboration, reproduction and correction of an anticipating algorithm or prototype of actions leading to achieving the goal; structuring of these actions in a certain way, giving them expedience and succession, without which the actions themselves are only single, fractured acts not connected in a common process;

- Communication of the programme with the agents, monitoring of their activities under it.

From here programming appears to be an important element in the purposeful systems, a special variety of which organizational systems appear to be. Organizational system in its essence is such a system, which purpose is coordination of the actions of the purposeful parts, what the social groups and individuals are, and goal direction (activity means and objects) with the global goal, namely - getting certain result (basic end product). Said in other words, programming after definite form and way connects the purposeful part of the organizational system with the means and the objects of activity. This way hierarchy, distribution of powerordering and executive functions among the programme subjects occurs (Terziev, 2013).

The strong interrelation between the forms of organizational system and programming is to be taken into consideration. "The hard" (relatively called "administrative-commanding") organizational system, as a rule, determines the corresponding forms of programming and the types of programmes from directive plan type. "The soft" ("liberal-democratic") system determines only the general reference points and recommendations for their achieving. In practice however we may see also various symbioses between "hard" and "soft" systems in the multiple combinations of programming (Terziev, 2013).

This is one side of the interrelation between the forms of the organizational system and programming. Not to be ignored is the other side, where the manifestation is in the reverse impact of the form of programming and its product - the programmes, upon the organizational system. The elaborated and fixed in certain from programme might determine certain shape of the system. The changes in the programme (the corrections), as a rule, lead to corresponding changes in the system.

Programming is directly related to another historically worked out approach for managerial influence. The word goes about culture. Here also, a deep interrelation is found, rooted in the essence of culture. It, the culture, is reviewed as "specific human method of activity", as "combination of sustainable forms of activity". It is in the base of the life activity of the single individual or the personal culture, the culture of the social group or the class culture, or the culture of the society as a whole. Such approach is supplemented by the axiological or the value essence, which manifestation lays in the fact that culture is observed as "combination of human values", as all that elevates, ennobles, and humanizes life and human relations. The sociological approach to culture, according which it is understood as "specific, genetically not inherited combination of means, methods, forms, samples and reference points for interaction between people and the inhabited environment, which they work out in their concomitance for maintenance of certain structures of activity and communication" finds further development in the recent years. Sociological approach observes culture as „system of collectively accepted values, beliefs, samples and norms of behaviour, inherent to a certain group of people ... Culture - this is "the collective programming of human intelligence, which distinguishes the members of a group to another". The point that the general level and the characteristics of culture have significant effect on the forms and the content of social programming in a certain society should also be taken into consideration. Social programming, in its cultural mien (aspect), is grounded on the fact that only the social relations contributing to human personality progress could create all necessary preconditions for the "algorithmic manner of culture" as way for acting to become consecutively rational, overcoming the 
stochastic subjectivity, the elemental uncontrollability and the preconditions for that, the free human activity to constantly ensure the outcome of these "algorithms", the elevation to the methods of activity, renewed by the own human deeds for creative capabilities. Here the complete manifestation of the essence of social planning lays in its creative influence upon social reality, ensuring its practical transformation in compliance with the adequately recognizable values of human world.

The approach towards culture as codified system (and, as a rule, reflected in bearers of various type), samples and norms of behaviour, activity, communication and interaction among people, who carry regulative and controlling function in society, deepens the understanding of its interrelation with social programming. Elaborating form and way of acting, which manifestation is in all the elements in the programmes, starting from revealing the goal and finishing with verification of the achieved result, happens on the grounds of the value orientation of subjects, the realizing and choosing the most significant needs and ones or others ways for their satisfying. This, in its turn, is connected with the normative side of culture, which, through the programming gets regulative-managerial solution. And here the manifestation of the ambiguous connection of programming and the market with its "invisible hand" is.

At first sight, the contradiction between the two categories imposes itself. Programming - with its immanent characteristic towards introducing system, structuring of processes, formalization of the impact upon them, and the market - with its classic characteristic of elemental interweaving and collision among the various public forces (Terziev, 2013). A more extensive study of the essence of these categories reveals number of connecting moments. After all, social programming should be distinguished through market, as a social institute, with the state programming of economy of market nature, and through it the social sphere, too. The first one of them appears as social programming, through the "market's invisible hand", found yet by Adam Smith. "Market's invisible hand", programming the egoistic interests of producers and consumers, directs them towards a goal that is not within their intentions. Following their own interests, they undertake actions that serve the interests of society (Terziev, 2013; Terziev, 2014). In compliance with that, the effective social programmes are to foresee the benefits from the investments in one or another component of theirs. The state programmes entirely financed by the state budget are not effective either economically or socially as far as economy as a whole defines society's wealth by definition. Programmatically, Adam Smith expresses this statement in the principle "Laisser faire", according which single people and enterprises are obliged to act in the economy without the intervention of state. This status is not realized in any country in absolute appearance in the practice of the social-historical development of that time. However, the intervention of state in the economy to the $20^{\text {th }}$ century is "passive", incidental and in most of the cases bears the character of extraordinary measures in times of wars or of indirect regulating by the means of legislation and the monetary system (Terziev, 2014). The system intervention of state in the economic and other field of public life increases in the $20^{\text {th }}$ century. Within that general trend, one of the central places is occupied by the issue for the correlation between the state regulation and the market self-regulation. Experience outlines three directions (models) at solving this issue, namely - in the USSR and the group of countries from Central and South-Eastern Europe, Central and South-Eastern Asia, known as socialist countries. According to the generally accepted terminology in the "communist block" to the beginning of $90 \mathrm{~s}$, under the influence of the Marxist doctrine and its modifications, a model of centralised, directive planning of economic and social development, rejecting the market, is realized. And alongside with the process of nationalizing the economy, growing of the spheres of social life, directly or firmly regulated by the given system was going on (Terziev, 2014). Within that model, number of methods, particularly the balance one and the normative one are found, practically applicable in each form of programming. This model gives also stimulus for elaborating the methodology and experience for social planning, social design and some other forms for social programming.

In a principally different direction, to the 30s, the practice of 'passive' participation of state was going on in the economy of the other countries, where the term 'planning', according to a F. Polak note, is a curse. According to him "... the deep economic crisis in the 30s that has come after countless other disasters, that has shaken the very base of the western system of production, produces a revolution also in economic thought" (Vasilyev, 1999). This revolution, connected with J. Keynes doctrine use, supposes "active" state intervention, including with the help of programming in the economic sphere. In the beginning of the 30 s, projects for state programmes appear in many countries, which goal is to reduce unemployment and to soften the other manifestations of crisis (in particular, "the Papen Plan" in Germany, "the Marquet Plan" and "the Plan for Mobilisation of Economy for Creating New Social Order" in France), "The Programme for the Tennessee River Valley Development in the USA", etc. (Vasilyev, 1999). Programming started being actively applied in the activity of the companies, the Ford factories, the Lockheed Company, etc. (Vasilyev, 1999).

Programming has special stimulus after the Second World War in Western Germany (in connection with „the Marshall Plan"), in France (State Plan for Development of National Economy for 1947-1952), in Japan and 
number of other countries (Terziev, 2014). Contradictory phenomena are observed in the further development of state programming in the countries with market economy, connected with increasing at times, decreasing at other times state intervention in certain social-economic and political situations. As a whole, "the joining" of market factors with programming becomes one of the leading trends in social development. Nevertheless, the thesis "Laisser faire" is not forgotten and is not thrown out of political dictionary. It acts as a principle of the public forces that contain the immanent forces of each country to subdue everybody and everything. Practically, each company elaborates perspective and current 'business plans', marketing projects, programmes for work with the personnel and other similar programmes. Within programming technologies like "indicative planning", "planning-programming-budgeting" (PPBS) and others are found and elaborated. International social programmes that take into consideration the market conditions in their realization are elaborated under the aegis of the international organizations (UN, UNESCO, EU, International Labour Organization, etc.). In this complicated structure, even at national level, 'the law for planned and proportionate development' is not realized, because of which the system of total state directive planning is constructed. It is the one that gives its possibilities for certain organization of interaction among the interested participants in socially significant activities.

Programming is mechanism that refers to the class of the very complicated systems, where the components possess great freedom of behaviour. The connection among the elements as well as the one of the system with the environment, are distinguished with flexibility and instability. Element exchanges the order. The system's composition and structure are not precisely defined; its boundaries are not precisely set. A lot in the system is unclear, indirect, "distorted". This gives us grounds to define it as arranged-elemental process. Despite that, the term leaves the plane of political and ideological reasoning on the subject "to be or not to be" and comes into use of public management with the requirement for deep theoretic and methodical revision and methodical-technological rationalization, which manifestation is in the elaboration of programmes as expression of the prescribing (deontic) side of human activity.

\section{CONTROLLING CONCEPT}

Scientific thought marks new stage in its conceptual improvement regarding control and its various practiceapplicable forms through defining controlling as an independent concept. The issue of managerial concepts origin and of their priorities in management is an issue connected with the factors that ground the success of the economic organization. Each historical epoch contains in itself specific factors of success, forming various managerial views and theories in the order of the day.

Controlling is also social-historical product, which stresses on specific circle of topical factors of success and their corresponding managerial aspects. In this sense, it has partial character, even in strictly defined historic moments; it does not exhaust the entire subject field of management and its theory. The factors of success embraced by controlling, however, have such fundamental significance in the conditions of developed market economy, that they are grounds of continuous actuality and the key role of that concept for the economic organization development.

The fundamental staring precondition of controlling contains in market economy establishing and the establishing of the economic organization as subject of commodity-money relations. Economic organization's monetary goals come in the foreground and get significant priority in these circumstances. In different, but significant enough extent, material and social goals, all spheres of its functioning turn being in their subjection. Monetary goals and the financial-economic aspects of all economic organization's activities grounding their achieving acquire criteria role in its existence and development.

Controlling as a managerial concept plays the important role to give the activity purpose towards the desired financial results. Controlling as managerial activity, functionally and as content, develops and improves, overbuilding certain basic positions of control, as a managerial function, transforming them to a higher level under the influence of additional, immediate preconditions (Dayle, 1994; Mishin, 2002).

Table 1. Analysis and prognosis of external environment (Han, 1997).

\begin{tabular}{|c|c|}
\hline Vision & \\
\hline Mission of organization & \\
\hline Planning of strategic goals & CONTROL \\
\hline Project planning & \\
\hline
\end{tabular}


IJASOS- International E-Journal of Advances in Social Sciences, Vol. VI, Issue 16, April 2020

\begin{tabular}{|c|c|}
\hline Operative planning & \\
\hline Regulation and control & \\
\hline Current activity (realization) & $\begin{array}{r}\text { analysis and prognoses on the organizational } \\
\text { activity }\end{array}$ \\
\hline \multicolumn{2}{|c|}{ Controlling within the frame of the organizational managerial tasks } \\
\hline
\end{tabular}

The first one of them is connected with the economic organization's internal environment, with increasing the dimensions, with complicating its activity and organizational structure and turning them more dynamic. The influence of the second immediate precondition for controlling is in the same direction - complicating economic organization's external environment and making it more dynamic. The first signals about the external environment come from the market situation. After that, the boom of avant-garde technologies, political, social and ecologic pretensions of the state towards the economic subjects, the escalating process of globalization are added to the changing world of marketing. The issue for the realization of the economic organization's monetary goals through harmonization of its complicated structures' efforts grows into issue for harmonizing organizational existence in the fast changing world (tabl. 1).

The concept for controlling evolution is connected with its establishing and is widely included in the theory and practice of managing from the end of the 30s of the 20th century. The world economic crisis exercises influence upon the development of controlling and its introduction to a significant extent. The years of depression accelerate the process of realizing the dependency between successful management and the internal organizational planning and reports. If we associate the historic-accounting interpretation of controlling with this period, then its weight and functions orient towards future events. Namely, the deepening of that trend establishes the actual essence of controlling by putting the conceptual stress upon planning and control. In this opening stage of the controlling concept's development, the American scientific thought has leading role as well as the established for the needs of industry Controllers Institute of America. Controlling tasks systematization and regulating the expert controllers authorities lay in its activity (1994a).

Certain approach towards the controlling concept forms in the middle of the 50s in the German economic literature. The provisional bridge that realizes controlling theories widening, is actually the branches of American concerns in Europe, and in particular in Germany, where the "modern"(Horvath, 1991) concept in used in certain administrations. Although it is spoken about just an idea, economic circumstances, the specific needs and definite differences in the theoretic works in managing, including the intellectual environment grounded on people's mentality, are substantial enough base for the differentiated development of two school in controlling - the American and the German on.

Especially after the 70s, the concept consecutively formats as theoretic system, and alongside it institutionalizes into managerial and educational system (especially in the German speaking countries) (Han, 1997; Ehrmann, 2000). As the most significant grounds for that, they accept the establishing of the managerial practice for the actuality and significance of the issues laid down in the concept (Han, 1997). In this sense, the sources and stimuli regarding the concept's establishment seem to be rather directed towards the intuitive rationalized needs of practice compared to giving new meaning to the paradigms of the known theoretic managerial models. Actually, if we carefully take a look at the controlling concept genesis division into periods, we'd find that each of it stages has in its base the transformation towards meaningful change regarding the central model for the factors of organization's success - the 30s - CVP; the 70s - the du Pont's method; the 90s - the EVA model, etc. (Karminskiy, Olenev, Primak, Falyko, 1998).

The traced evolution and the created situation precondition the increasing pressure for establishing concept's identity as an independent scientific and education discipline. It is pointed out that it is in a stage of theoretic development, with proved conceptual and empiric insufficiency, and at the same time is not based on perfect structuring of management. This could be explained with concrete difficulties connected with own field of study and training in spheres that are already occupied by other disciplines as managerial accounting, information systems, planning, analysis, control, etc. Similar opinions are maintained by the controlling concept leading followers themselves, among whom significant differences continue existing regarding its subject, scope, purpose and theoretic grounds. It is considered that the emerged in the $80 \mathrm{~s}$ in Germany three basic conceptual approaches reviewing it correspondingly within the frame of managerial accounting, of information systems (Reichmann, 1990) and of the systems for management (Pich, 2001) still 
preserve their division. The basic points of all three approaches, to one or another extent, and under various forms, find conditions for settling and development in German speaking and part of the post socialist countries.

The forming of principle differences in content aspect in the process of controlling concept improvement between the German and the American theory and practice is another substantial moment of the concept's development. The German concept defends to a greater extent the managerial purpose of controlling and its engagement with future. This fact fixes the main precondition for the concept transformation in ideacontaining aspect, directing it towards information-analytic functionality. It frees from servicing external users through preparation of externally regulated accounting reports as well as with solving tax and insurance problems, which again are connected with external factors (Mann, Mayer, 1992).

The situation with the American position is different, where controlling is observed in a wider aspect. Additional functions and tasks are usually included in its subject on the grounds of financial-accounting purpose as part of the controlling concept. Besides the managerial accounting, the financial-accounting reporting regarding the realization of tax and insurance programmes for conducting internal revisions (audits) (Simeonov, 2001a) is added. Still, sufficient grounds are accumulated for achieving unity between the existing views and the forming of one, homogeneous to a sufficient extent, controlling, its sources and main directions of development.

In order to analyze the value of the content changes and the role of controlling as a substantial stage in the development of managerial thought, it is of significant importance to analyze the connections of the concept with the management main functions. The understanding that controlling could be interpreted as coordinate system of the classic formulation for the management functions predominates. From this point of view it, as a rule, is connected with the functions on planning and control (Simons, 1994b; Horvat, Zaydenshvarts, 1993) after all. This finds expression in the standards for the functions and tasks of the controller, adopted by the Financial-Administrative Institute (FEI) and the International Group of Controlling (IGC).

The objections on the behalf of the opponents of the concept, most of the times, are grounded on the insufficient argumentation regarding the necessity of new review about the structure of managerial functions, which specifies the place and role of controlling (Beker, 2001b; Terziev, 2014). Actually, the statement that the controlling concept represents a try for classic views revision suffers insufficient argumentation. The conclusion that modern conditions impose new approach towards the practical realization of the managerial functions can be drawn from the analysis of various competent opinions. The stress of that approach is focused upon the synthesis in the planning and controlling functions realization on the grounds of the feedback new role in managing. Considerable consensus is achieved that namely this new role is a key element in the controlling concept and a main source for its origin and development (Rubtsov, 2001c).

The motives for such an understanding find grounds in the brightly manifested and indisputable, especially after the 70s of the last century, necessity of a flexible managerial reaction as opposition to the radical largescale and fast changes in the organizations' environment. In this context, the indications from the control function are reviewed to a greater and greater extent as ruling in regard to the process of planning in comparison to the process of the plan's implementation. Namely that fact preconditions the practical realization of the activities of planning and control as a unified process, where central place is determined for the controlling function (Schneider, 1992a) at comparing planned with factual status and diagnostics of deviations.

In the second half of the 90 s, this approach, to a greater and greater extent, dominates not only in the operative-technical but in the strategic planning-controlling process, too. The controlling concept purposefulness towards this new practice approach at implementing the activities of planning and control is supported by the opinion that controlling, narrowly meant, is identified with the mentioned element of the controlling function. The new role of modelling the target function of the economic organization could be defined as another concept's key element. This element has particularly important significance for defining the controlling subject and for elevating its independent role, where it could be mentioned that this statement finds only indirect support in certain scientific circles (Malaysheva, 2002a).

The character, scales and speed of the changes on the organization's environment during the second half of the 20th century grounded dynamics not only in the meanings of the plan indicators but also in the character of the indicators themselves and in the models of its success. This transformation concerns the target as well as the factor variables (Kaplan, Kuper, 2007) of these models, in operative and strategic aspect, and this problem falls into certain vacuum, created between the combinations of managerial disciplines, and was not entirely covered by any one. Just that fact turned into source, which registers and specifies sovereign territory to controlling in the person of economic organization target function's modelling. From the point of 
view of the pointed controlling concept's key elements, we can relate and rationalize it as certain combination of methodological and methodical approaches for modelling the target function, setting and reaching optimal values of its variables in the plan control process through elevating the role of the feedback in managing. The significance of the pointed out thesis requires several clarifications:

First - it is usually emphasized that controlling does not correspond to the effective goal defining as well as to its meaning, where it is accepted that this is a prerogative of the owners and the higher managers. In the end of the 90s of the 20th century, however, solving the problem with the economic organization's goals acquires poly-variant nature and does not look trivial anymore (Mintzberg, Ahlstrand, Lampel, 1997a). In the condition of the role, assigned to the controlling concept in the process of modelling the organization's target function being recognized and established, the searches in this field would completely naturally fall into its range of vision. Only a positive result out of these searches could form reliable base for further outlining the circle of factor variables and heir limitations as well as of the criteria for the target organizational function's optimization;

Second - the feedback in the process of management has to deal with not only the realization of the particular meanings of the variables included in the organization's target function, but also with the architecture of the function itself. The dynamic, unexpected, and in many cases radical change of the success factors provokes necessity of constant estimation for the actuality of the chosen model, which feedback it should satisfy. Indicative in this regard is the estimation of the key management models form the end of the 20th century (Stern, Shiely, Ross, 2001d) (EVA, etc.) through considering the quite increased impact of non-material factor variables (Kaplan, Norton, 1996; Terziev, Georgiev, 2017; Georgiev, 2017a);

Third - the defining of the controlling concept after the mentioned above way supposes it serves with approaches for metrifying and standardizing the views for economic organization's functioning and developing. In this sense, it could be perceived as concept for realization of the concepts for the economic organization. The word goes about giving new meaning and pre-formulating of particular content concepts through the process of metrifying in the target function and its differentiation into base of planning-controlling process under the form of standards. From the point of view of feedback in the reviewed process, controlling acquires one more function - to test the viability of these concepts. This grounds specific for the controlling technology and standardization of processes of planning and control, which in a wider plane could be reviewed also as technology of management (Kamenov, Damyanov, 1994c);

Fourth - obviously, the target function modelling and its model further using for prognostication, design and control in the planning-controlling process require such large-scale information preconditions that controlling naturally embraces the key information activities, including the one on accounting in the organization. From the position of this understanding, the conflict points are usually differentiated with the inclusion or exclusion of financial accounting from the perimeter of controlling. The conceptual approach to this problem requires the significance according, which financial accounting secures the controlling goals realization to be registered. Here it should be pointed that if the trends from the end of the 20th century continue - then this accounting moves further away from the needs of internal organizational management, then increasing the distance between it and the controlling processes could be expected. The presented approach in the process of fixing and formulating the controlling concept's subject gives the necessary quantity of arguments as grounds of the multiply expressed belief that controlling plays coordinating role in the economic organization's management. On one hand the word goes about content coordination from the shared opinion on the organization's target function's point of view, and on the other - about technological coordination from planning-controlling process standardization's point of view. In the line of these thoughts, a dilemma arises is the coordination of management to be differentiated as independent, summarizing managerial function, which realization controlling serves. At this stage of scientific thought development, and from the analysis of the above grounded argumentation, such end conclusion for solving the mentioned dilemma is not to be apprehended (Ovcharova, 2007a-b; Terziev, 2015).

Revising the significance of the controlling concept in the process of improving the functionality of management, its role in the process of taking managerial decisions could not be ignored and even depreciated. This process goes through several summarising stages: localization of the arising problems and defining their priorities; elaboration of alternative variants for solution, evaluation of these variants and selection of preferred one; undertaking measures on the realization of the preferred variant. It is becoming obvious from the above that controlling has to deal with taking decision in planning and control of all business functions realization (Terziev, 2015) - production, supply, sale, development activity, etc. as well as with all managerial levels. However, here specification of its role from the applied methodological and methodical approaches' point of view is necessary.

The position that controlling is information-analytic activity that has subsidiary role in the process of taking 
managerial decisions predominates (Terziev, 2015). This position finds development and substantial supplement in the interpretation that in its nature and essence it is internal-managerial consulting for the various hierarchical management levels in the modern organization (Terziev, 2015). This is set in the base of the target job description of the controller, acquired by the International Group of Controlling (IGC). It comes from here that controlling is not directly connected with the act of taking managerial decisions, which is prerogative to the ones delegated to manage, but only - with the process of their preparation. A certain compromise in this regard is made with the possibility the controlling bodies to be able to impose deferral veto on the decisions of the lower management levels.

Similar approach that defines the subsidiary and consulting role of the controlling bodies in the process of taking decisions is completely logical and grounded. The arguments are rooted in the specific point of view of the controlling concept regarding the organizational problems. The presented up to here position about the functionality of controlling localize this point of view in the field of management as science. This defines its specialization and hence insufficiency for thorough covering the process of taking decision, including its power aspect. The subject of power and managerial decisions should unite organically the resources of management as science as well as of management as art. As far as the resources of science require specialized mastering, regarding them it needs help. The controlling activities are predetermined to realize just that role. This statement, however, is quite general and needs specifying. It concerns the attitude of controlling towards both main levels of scientific knowledge - scientific heuristics and system analysis. The suggested emphasis upon the responsibility of controlling for modelling organization's target function and the further use of the model in the planning-control process leads to its unconditional engagement in the theory of system analysis. It could be said here that the word goes about mastering and application on the highest level of knowledge in the circumstances of a particular organization. Namely from that level and in their capacity of system analyzers, the bodies of controlling are expected to realize their consulting activity, where the indirect support for this interpretation is set in number of stipulations of the IGC standards for the controller's target picture. The consulting role from the system analysis position further predetermines a specific approach in the process of its realization. It could not be imperative approach but one of grounded explaining and motivated convincing - approach of effective cooperation. An important place is assigned to its toolkit for the shaping of an entire and complete image of the controlling concept present status. The interdisciplinary character, the proved poly-functionality and the increasing perimeter are the substantial preconditions determining the great variety of the tools arsenal. Central place is occupied by the systems of plans and plan-control reports in this diversity. Their elaboration is function from the use of wide range of supporting methods and models for planning and prognosticating, for revealing and analysing connections and subordinations, for measuring the factual status, for diagnostics of deviations and for optimizing.

The system of plans as well as the system of planning-controlling reports has in its base the structure of planning-controlling indicators, which in their entirety and internal connections represent the financialeconomic model for the organization's financial results. In this sense, the model has starting role in the systematic organization of the planning-controlling activity, and it in its turn, updates it continuously , enriches it, develops it further (Terziev, 2015) and improves it.

Controlling, as an integrated combination of planning and controlling activities, requires also, as its precondition, the availability of managerial information system, which to ensure combining of multidimensional databases, models and their free structuring, to ensure integration of various managerial models and methods for information insuring in real time, to realize continuous adapting to the vertically and horizontally extending database with the subject and the objects of planning and control (Terziev, 2015). In their unity, the systems of plans and planning-controlling reports, the financial-economic model for financial results, the combination of subsidiary models and methods and the managerial information-accounting systems form the basic poly-component structure of controlling toolkit (tabl. 2).

Table 2. Basic component structure of controlling toolkit.

\begin{tabular}{|c|c|c|}
\hline $\begin{array}{l}\text { Methods and models for } \\
\text { planning and control Methods } \\
\text { for: prognosticating, linear } \\
\text { planning, CVP analysis, the } \\
\text { function of demand, models of } \\
\text { orders and stock, ABC method, } \\
\text { FSMA, model of du Pont, model } \\
\text { of financial leverage, etc. }\end{array}$ & $\begin{array}{c}\text { Plans - basic indicators - } \\
\text { actions - budgets - schedules } \\
\text { of revenues and payments } \\
\text { Planning-controlling reports - } \\
\text { ascertainment part - analytic } \\
\text { part }\end{array}$ & $\begin{array}{l}\text { Financial-economic model of } \\
\text { enterprise - basic target } \\
\text { indicators for the financial result } \\
\text { and the liquidity - basic } \\
\text { indicators by functional spheres } \\
\text { and sub-divisions }\end{array}$ \\
\hline
\end{tabular}


IJASOS- International E-Journal of Advances in Social Sciences, Vol. VI, Issue 16, April 2020

statistic and other managerial accounting - system for financial accounting reporting - integrated managerial information system (ERP, MRP, etc.)

\section{Basic component structure of controlling toolkit}

Tracing the genesis of the controlling concept and the processes on its ideological improvement, content enrichment, territorial extension and on increasing of its toolkit provoke one more conclusion that proves the correct direction of change - the purposeful moving from operative-technical to the strategic centre of conceptual development (Terziev, 2015). Several facts that support the conclusion and mark out the ways of conceptual improvement exist:

First - the complicating and development of one of the conceptual approaches for the controlling development, originating from Germany in the $80 \mathrm{~s}$, corresponding predominantly with the management systems that have found intellectual soil and economic environment for dissemination in number of destinations (German speaking countries, and in particular, post-socialist);

Second - the registering and the establishing of controlling important role regarding modelling the target function of the modern "strategically oriented” economic organization;

Third - the introduction and imposing in practice key managerial models from the end of the 20th century with regard to the dominating influence of the non-material factor variables included in them and their increasing strategic weight.

\section{CONCLUSION}

All the written forms the summarizing opinion that social programming is in direct connection with the modern management theory and its modern approaches oriented towards actually achievable results. In this context, interdependency manifests between social programming reviewed as base for regulating social development and its grounding concept for controlling, reviewed as technology as well as standardization. Actually, this trend, interpreted in a narrow sense, is a possibility for optimization of the processes of planning and control, based on the functional approximation and consolidation, and reviewed in a wider plane as "good" managerial practice. Controlling, as an integrated combination of planning and controlling activities preconditions the availability of managerial information system, which to provide for matching of large data bases, models and their free structuring, to ensure integration of various managerial models and methods for information ensuring in real time, to realize continuous adapting of the vertically and horizontally extending database with the subject and the objects of planning and control, which appear to be inseparable part of the process-developing system of social programming. Objectively viewed, namely the tight approximation of the leading in controlling managerial functions create conditions for acquiring sufficient confidence in the creation and the development of a sustainable and relevant to the conditions and the social-economic situation social policy (Terziev, Stoyanov, Georgiev, 2017c-g).

\section{REFERENCE LIST}

Terziev, V. (2013). Vazdeystvie na politikite na pazara na truda za osiguryavane na zaetost. Izdatelstvo „Dema Pres - Ruse“, 2013 (Терзиев, В. Въздействие на политиките на пазара на труда за осигуряване на заетост. Издателство „Дема Прес - Русе“, 2013).

Terziev, V. (2014). Vazmozhnosti za povishavane na efektivnostta na sotsialnata adaptatsiya na voennosluzheshti, osvobodeni ot voenna sluzhba. Izdatelstvo „Primaks“ - Ruse, 2014 (Терзиев, B. Възможности за повишаване на ефективността на социалната адаптация на военнослужещи, освободени от военна служба. Издателство „Примакс“ - Русе, 2014).

Due J. and A. Friedlander, (1977). Government Finance Nomewood Illinois, 1977.

Dickermann D. und andere. (1971). Das Rationale Budget Kolner Universitats-Verlag 1971.

Strategie Planning aug Policy (1979). N. Y. 1979.

Vasilyev, V. P. (1999). Sotsiologicheskaya problema upravleniya i sotsialynoy zashtita. Sotsiologicheskie issledovaniya, 1999 №11.Васильев, В. П. Социологическая проблема управления и социальной защита. Социологические исследования, 1999 №11.

Dayle, Al. (1994). Praktika Kontrollinga, Moskva, 1994 (Дайле, Ал. Практика Контроллинга, Москва, 
1994).

Mishin, Yu.A. (2002). Upravlencheskiy uchet - Monografiya, M., I-vo "Delo i servis”, 2002 (Мишин, Ю.А., Управленческий учет - Монография, М., И-во "Дело и сервис", 2002).

Han D., (1997). Planirovanie i kontroly: kontseptsiya kontrolinga, M., F i S, 1997 (Хан Д., Планирование и контроль: концепция контролинга, М., Ф и С, 1997).

Baan Deutschland/GmbH/ (1994a). Controlling, Hannover, 1994.

Horvath, P. (1991). Das Controlling -Konzept, Munchen, 1991.

Ehrmann, H. (2000). Kompakt - Training Balanced Scorecard, Ludwigshafen, 2000.

Karminskiy, A., Olenev, N., Primak, A., Falyko, S., (1998). Kontrolling v biznese, M., FiS, 1998 (Карминский, А., Оленев, Н., Примак, А., Фалько, С., Контроллинг в бизнесе, М.,ФиС, 1998).

Reichmann, T. (1990). Controlling mit Kennzahlen, 2.aufl. Munchen, 1990.

Pich, Sherm. (2001). Utochnenie soderzhaniya kontrollinga kak funktsiya upravleniya i ego podderzhki, 2001 (Пич, Шерм. Уточнение содержания контроллинга как функция управления и эго поддержки, 2001).

Mann, R., Mayer, Z. (1992). Kontrolling dlya nachinaushchih /per.s nem./ M., FiS, 1992 (Манн, Р., Майер, 3. Контроллинг для начинаушчих /пер.с нем./ М., ФиС, 1992).

Simeonov, O. (2001a). Kontroling. Izd. Trakiya-M, Sofiya, 2001 (Симеонов, О. Контролинг. Изд. Тракия-М, София, 2001).

Simons, R. (1994b). How new top managers use control systems as levers of strategic renewal. Strategic Management Journal, 1994, XV.

Horvat, P., Zaydenshvarts, V. (1993). Kontroling, V: Menidzhmant: Upravlenieto na prehoda, S. 1993 (Хорват, П., Зайденшварц, В. Контролинг, В: Мениджмънт: Управлението на прехода, С. 1993).

Beker, A. (2001b). Uchet dlya "Kontrollinga". Protivorechiya v teoreticheskih osnovah upravlencheskogo ucheta i upravleniya $v$ nemetskom biznes administrirovanii /per. s angl./ 2001 (Бекер, А. Учет для “Контроллинга". Противоречия в теоретических основах управленческого учета и управления в немецком бизнес администрировании /пер. с англ./ 2001).

Rubtsov, S. (2001c). Tselevoe upravlenie v korporatsiyah, М., ABВ, 2001 (Рубцов, С. Целевое управление в корпорациях, М., АББ, 2001).

Schneider, D. (1992a). Investition, Finanzierung und Besteurung, 7. aufl., Wiesbaden, 1992.

Malaysheva, L. (2002a). Kontrolling na predpriyatii, М., 2002 (Малышева, Л. Контроллинг на предприятии, M., 2002).

Kaplan, R., Kuper, R. (2007). Funktsionalyno-stoimostnoy analiz, M., Vilyyams, 2007 (Каплан, Р., Купер, Р. Функционально-стоимостной анализ, М., Вильямс, 2007).

Mintzberg, H., Ahlstrand, B., Lampel, J. (1997a). Strategy safari. A Guided Tour Throut the Wilds of Strategic Management, 1997.

Stern, Shiely, Ross, (2001d). The Eva challenge: implementing value added in an organization, HBR Press, 2001.

Kaplan, Norton, D. (1996). The balanced scorecard: translating strategy into action, 1996.

Kamenov, K., Damyanov, А. (1994c). Kontroling, izd. "Tsenov", Svishtov, 1994 (Каменов, К., Дамянов, А. Контролинг, изд.“Ценов”, Свищов, 1994).

Ovcharova, Sn. (2007a). Knowledge management in some Bulgarian organizations. 6th International congress “Knowledge Economy \& Management", 26-28 Dec.2007, Istanbul, Turkey, 2007, pp.19081915. ISSN 1308-3937.

Ovcharova, Sn. (2007b). Motivation in knowledge economy. 6th International congress "Knowledge Economy \& Management”, 26-28 Dec.2007, Istanbul, Turkey, 2007, pp.1643-1651. ISSN: 1308-3937.

Terziev, V. (2015). Predizvikatelstva pred sotsialnoto programirane v konteksta na nasarchavaneto na sotsialnata aktivnost i reguliraneto na sotsialnoto razvitie chrez aktivni politiki. Izdatelstvo „Primaks”, ISBN 978-619-7242-02-7, Ruse, 2015, 375 str. (Терзиев, В. Предизвикателства пред социалното 
програмиране в контекста на насърчаването на социалната активност и регулирането на социалното развитие чрез активни политики. Издателство „Примакс”, ISBN 978-619-7242-02-7, Русе, 2015, 375 стр.).

Terziev, V., Georgiev, M. (2017). Highlights of the evolution of the „Balanced Scorecard“ idea as a model for managing strategy development and control. // SOCIOINT 2017- 4th International Conference on Education, Social Sciences and Humanities 10-12 July 2017- Dubai, UAE, OCERINT- International Organization Center of Academic Research, Istanbul, Turkey, 2017, pp. 607-610, ISBN: 978-60582433-1-6.

Georgiev, Marin. (2017a). The Role of the Balanced Scorecard as a tool of strategic management and control. // Journal of innovations and sustainability, Plovdiv, Bulgaria, 3, 2017, N 2, pp. 31-63, ISSN 2367-8127 (CD-ROM), ISSN 2367-8151 (on-line).

Terziev, V., Nichev, N., Stoyanov, E., Georgiev, M. (2017b). Key aspects of the problems of administrative control in Bulgaria. // Proceedings of ADVED 2017- 3rd International Conference on Advances in Education and Social Sciences 9-11 October 2017- Istanbul, Turkey. International Organization Center of Academic Research, www.ocerint.org, 2017, pp. 707-710, ISBN: 978-605-82433-0-9.

Terziev, V., Stoyanov, E., Georgiev, M. (2017c). The factor information in the making of "the right" decision. // Scientific journal „Economics and finance“. Publishing house „BREEZE“, Current scientific research, Collection of scientific articles, Montreal, Canada, 2017, pp. 26-32, ISBN 978-617-7214-49-5.

Terziev, V., Stoyanov, E., Georgiev, M. (2017d). One solution for costs minimanization in the banking sector. // Scientific journal „Economics and finance“. Publishing house „BREEZE“, Current scientific research, Collection of scientific articles, Montreal, Canada, 2017, pp. 62-66, ISBN 978-617-7214-49-5.

Terziev, V., Stoyanov, E., Georgiev, M. (2017e). Accountable regulation of foreign exchange operations. // Scientific journal „Economics and finance“. Publishing house „BREEZE“, Current scientific research, Collection of scientific articles, Montreal, Canada, 2017, pp. 66-71, ISBN 978-617-7214-49-5.

Terziev, V., Stoyanov, E., Georgiev, M. (2017f). Specifics of control in operations with precious metals and precious stones. // Scientific journal „Economics and finance“. Publishing house „BREEZE“, Current scientific research, Collection of scientific articles, Montreal, Canada, 2017, pp. 71-76, ISBN 978-6177214-49-5.

Terziev, V., Stoyanov, E., Georgiev, M. (2017g). Intitutional team work -opportunity for improvement of financial control. // Scientific journal „Economics and finance“. Publishing house „BREEZE“, Current scientific research, Collection of scientific articles, Montreal, Canada, 2017, pp. 76-80, ISBN 978-6177214-49-5. 